Received 22.06.2016

Reviewed 18.07.2016

Accepted 20.09.2016

A - study design

B - data collection

C - statistical analysis

D - data interpretation

$\mathbf{E}$ - manuscript preparation

$\mathbf{F}$ - literature search

\title{
Using artificial neural networks to determine the location of wind farms. Miedzna district case study
}

\author{
Krzysztof POKONIECZNY ${ }^{\text {ABCDEF }}$
}

Military University of Technology, Faculty of Civil Engineering and Geodesy, gen. Sylwestra Kaliskiego 2, 00-908 Warszawa; e-mail: krzysztof.pokonieczny@wat.edu.pl

For citation: Pokonieczny K. 2016. Using artificial neural networks to determine the location of wind farms. Miedzna district case study. Journal of Water and Land Development. No. 30 p. 101-111. DOI: 10.1515/jwld-2016-0026.

\begin{abstract}
The article concerns issues pertaining to of selecting suitable areas for wind farms. The basic assumption of the study was to take into account both criteria related to the profitability of this type of power plant, as well as public interest, which means the harmonious and not burdensome functioning of these installations for local communities. The problem of wind farm localization may be solved by the application of artificial neural networks (ANN), which are a computational intelligence element. In the conducted analysis, the possibility of wind farm localization was considered for the primary grid field with dimensions of 100 by $100 \mathrm{~m}$. To prepare the training set, topographic vector data from the VMap L2 and SRTM (Shuttle Radar Topography Mission) digital terrain model were used. For each 100-meter x 100-meter grid, the input data was prepared, consisting of the factors which are important from the point of view of wind farm localization (forests, rivers, built-up areas etc.). Studies show that a properly trained neural network (using a representative number of samples and for the appropriate architecture), allows to process automation area classification in terms of placement on the wind turbines.
\end{abstract}

Key words: artificial neural networks, multilayer perceptron, wind farms localization

\section{INTRODUCTION}

A wind power plant generates electricity using generators (wind turbines) powered by wind energy. Fuel burning does not occur in this process. Wind power belongs to the group of "renewable energy sources" (RES). To increase the generated power, wind turbines are grouped into clusters called power parks or wind farms. A typical example of such farm is located in Western Pomerania (Postomino district). The Marszewo wind farm is the third largest wind farm in Poland [TAURON... undated]. It is formed by 41 turbines of $2 \mathrm{MW}$. Total installed capacity equals to $82 \mathrm{MW}$. Wind farms are composed not only of the turbines. It is necessary to build related facilities. The Marszewo farm complex consists of approximately $17 \mathrm{~km}$ of high voltage lines and $28 \mathrm{~km}$ of service roads. The farm is able to provide electricity to approximately 120 thousand households, which roughly equals the size of the city of Lublin. According to data from the Energy Regulatory Authority, by the end of September 2013, there were 795 wind turbines of various sizes in Poland. Due to good wind conditions, the largest installed capacity of wind turbines is in the north - western part of the country, i.e. in the West Pomerania Voivodeship (489 MW), the Greater Poland Voivodeship (238 MW) and KuyaviaPomerania Voivodeship (208 MW) [URE undated]. Worldwide, almost $1 / 3$ of wind power is generated in China. Leading manufacturers are also: the US (18\%) and Germany (11\%). Poland, with the production of $3,866 \mathrm{MW}$ [GWEC 2014], produces just over $1 \%$ of the world's wind energy. 
Currently, issues concerning renewable energy are extremely important in the European Union. The European Commission ratified the "Strategy 2020" document, which has been effective since 1 January 2011. According to its content, within 10 years - between 2011 and 2020 - the European Union will intensify activities in order to improve the economic situation. One of the most important elements is defined as the $3 \times 20$ bundle. It assumes that by the year 2020 greenhouse gas emissions will have been reduced by $20 \%$, while increasing energy efficiency by $20 \%$ and achieving a $20 \%$ share of renewable energy sources (RES) in the total energy production. The latter means that the importance of wind energy will be growing. That is why it is necessary to find more and more new areas suitable for locating wind farms. In Poland there has been developing steady increase of the energy production generated by renewable sources. In 2010 this percentage amounted to $6.9 \%$ (including $1.1 \%$ wind energy), whereas in 2013 - already $10.4 \%$ (3.7\% wind power) [ARE 2014]. Forecasts predict that in 2030 the production of the renewable energy sources will not exceed $18.8 \%$ of the total energy production assuming that in Poland nuclear power plants will be launched [Energetyka Cieplna i Zawodowa 2009-2010].

From the perspective of the above data, it is obvious that the importance of wind power in Poland will grow. However, there is an obvious problem. The indisputable advantages of wind energy (the possibility of obtaining a high capacity using modern wind turbines and lack of harmful emissions into the atmosphere) contrast with such problems as noise emitted by rotating turbines and birds killed by the rotating rotor blades. In this regard, both in Poland and in Europe, a growing number of social protests is being organized. Citizens, as is the case with nuclear power, understand the importance of renewable energy sources; however, they do not want this type of installations near their own residences. Taking this into account, this article concerns very important issues of selection of areas suitable for wind farms. The basic assumption of the study was to take into account both criteria related to the profitability of this type of power plant, as well as public interest, which means the harmonious and not burdensome functioning of these installations for local communities. The problem of optimal location of wind turbines has previously been raised in a paper [MONTUSIEWICZ et al. 2015]. For the purpose of that paper, GIS tools and multicriteria optimization methods were used, e.g. the Electre TRI method. This article proposes a different approach to this subject. This publication will take into consideration the widely used wind turbine with a capacity of approx. $2 \mathrm{MW}$. An example of this type of construction is the Vestas V90-2.0 MW turbine. This generator is approx. $100 \mathrm{~m}$ in height, has a rotor diameter of $90 \mathrm{~m}$ and weighs about $300 \mathrm{t}$ [Vestas undated].

\section{MATERIAL AND METHODS}

The problem of wind farm localization may be solved by the application of artificial neural networks (ANN), which are a computational intelligence element. The justification for their use is that they are applicable in solving problems in which we have to deal with a large amount of input data and in which the algorithm to solve the problem is unknown or difficult to implement [SUZUKI 2013]. This situation occurs in the discussed localization of wind farms there are multiple parameters entered into the analysis, related to topography or land cover, and a universal algorithm of operation is extremely difficult to implement. Artificial neural networks implement the requirements of fuzzy logic, and that is why we will be able to determine the usability of terrain in a continuous range, e.g. 0 and 1 (we are not limited to the binary classification). Therefore, it is possible to generate a continuous Index, which characterizes the terrain in a range from 0 (unfavorable area for wind farms) to 1 (area suitable for wind farms).

The core element of the artificial neural network are interactions between neurons (connected to each other) and the modification of the weight connections between them. This modification depends on input data and the expected output from the network as well. This process is called "neural network learning". The next step is the process of using only network input data (e.g. the operational usage of neural network).

There are input signals $(x)$ sent to the neurons, and for each connection there is an assigned value $(w)$ called the weight, which if positive, corresponds to the combination of the booster, when negative - inhibitory. After adjusting weights through the process of learning, data processing consists of calculating the total boost for each $k$-th neuron which has $M$ connections (net) [JING et al. 2012]:

$$
n e t_{k}=\sum_{i=1}^{M} x_{i} \cdot w_{i}
$$

To determine total neuron activation, it is converted to output value by processing through an activation function $f$. Thus, the final data processing by each neuron of the neural network (except for the input neurons) is expressed by the formula:

$$
y_{k}=f_{k}\left(\text { net }_{k}\right)
$$

In the studies performed, various functions of activation have been used, such as sigmoid, linear, sinusoid, logistic, etc. The advantage of using the continuous activation function is that the output of the neural network values falls in a continuous and standardized range from 0 to 1 . The above described operations are performed by each neuron of the network 
and are sent to the neurons contained in successive layers, up to the output [WIDROW, LEHR 1990].

Usage of this technology in cartographic modelling and terrain classification is not an entirely new concept. BAGHERI et al. [2015] presented an application of perceptron for classification of soil types, basing on the elements of land cover and the digital elevation model. The different architectures of ANN were used in the analysis. The authors obtained a very large discrepancy for the used test data - for one of the presented classification examples relative accuracy was in the range of 41 to $87 \%$. LEE et al. [2012] used perceptron in their experiments for predicting the production of surface water and the accuracy was between 74 and $80 \%$. This indicates an ambiguity in the use of ANN and necessity to perform final verification of the results. In the field of wind farms, artificial neural networks have been used in the work of NoOROLLAHI et al. [2016]. The authors applied the multilayer perceptron to predict wind power in the area of Iran. The results coincide very well with the results from measuring devices. The algorithm used in this work can be successfully used as a supplement to the research presented in this paper, because wind power is one the most important parameters for the land-planning process in the evaluation of possible installation of new wind farms.
The area of the Miedzna district (Fig. 1) was selected as the case study. It is located in the western part of the Mazovia Voivodeship, which is a district with an area of $116 \mathrm{~km}^{2}$. Most of its area is covered by arable land (68\%) and forests (29\%). The remaining area are the built-up areas and wastelands. The Miedzna district was chosen because of factors such as low population density ( 135 people per $\mathrm{km}^{2}$ ) and its agricultural character. Slight denivelations and a small number of natural and artificial obstacles make the area of the Miedzna district very suitable for the location of wind farms. Wind conditions for the area of the municipality have been identified as "quite favourable" (wind speed 4-4.5 $\mathrm{m} \cdot \mathrm{s}^{-1}$ ) [LORENC 2005].

In the conducted analysis, the possibility of wind farm localization was considered for the primary grid field with dimensions of 100 by $100 \mathrm{~m}$. The area of the Miedzna district with the surrounding $2 \mathrm{~km}$ wide buffer was divided into 24,755 mesh fields (Fig. 2). To prepare the training set, topographic vector data from VMap L2 and SRTM (Shuttle Radar Topography Mission) digital terrain model were used. For each 100-meter $\times 100$-meter grid located in this area, the input data was prepared. They consisted of the factors which are important from the point of view of wind farm localization (Tab. 1):

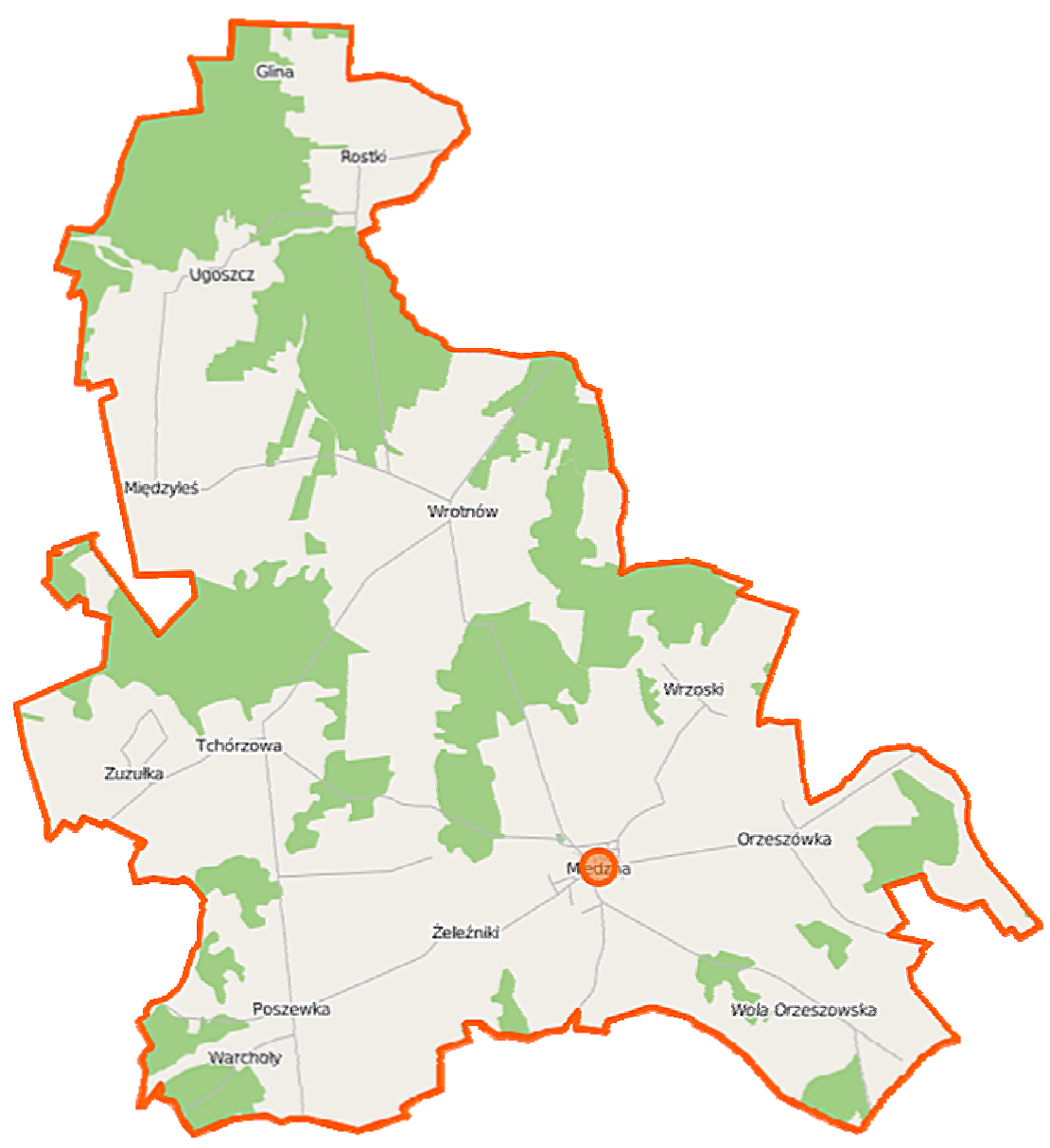

Fig. 1. Borders of Miedzna district; source: OpenStreetMap [undated], CC BY-SA 2.0 


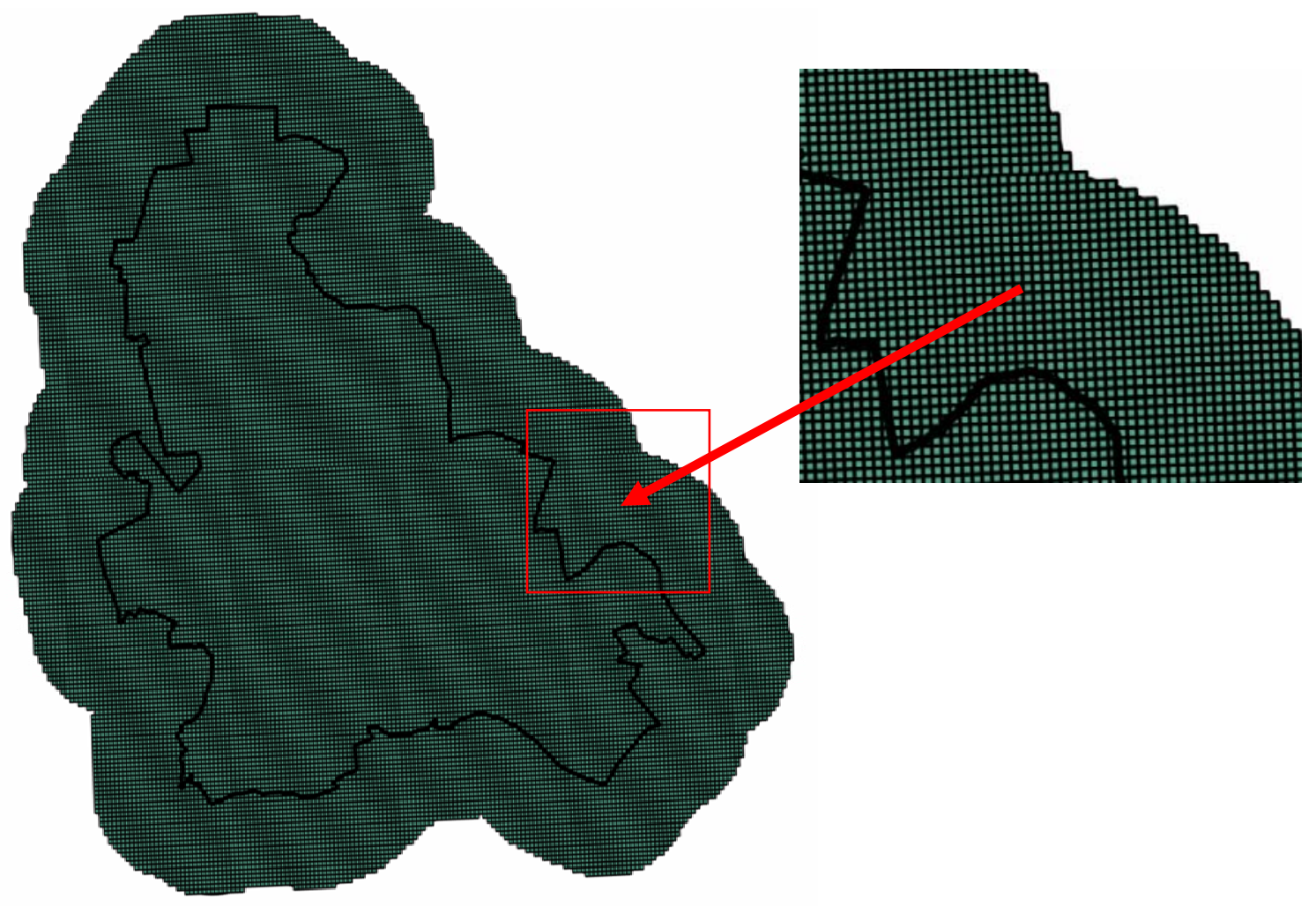

$\begin{array}{lllllll}1 & 0 & 1 & 2 & 3 & 4 & \mathrm{~km}\end{array}$

Fig. 2. Visualisation of the 100 by $100 \mathrm{~m}$ grid (24 $755 \mathrm{mesh})$; source: own elaboration

- average height - the value determined as the average height of the measurement points located in the area of the mesh (data collected from the SRTM);

- average slope - the value determined as the average slope of the measurement points located in the area of the mesh (data collected from the SRTM);

- length of rivers - the total length of rivers located in the area of the mesh (data collected from vector map level 2);

- distance to the nearest road, forest, built-up area and farm - distance from the geometric center of the mesh to the geometric center of the minimum bounding rectangle which encloses closest object of a particular class (Tab. 1). It should be noted that if any of these elements cover the area of a mesh field, the distance was determined automatically as $0 \mathrm{~m}$.

Visualisations of the prepared data are presented in Fig. 3. The use of a mesh in such small size enables the noting of the exact course of linear objects (roads, rivers) and detailed shape of the areal objects such as forests.

The next step was to prepare the learning set. This was done through a random selection of 248 mesh fields (ie. one percent) of all generated grid squares. This data was used for neural network learning. For each selected mesh field, the index of wind farm localization possibility was assigned for this grid in the continuous range 0 to 1 ( $\mathrm{I}_{1}$ factor). Output data for learning the neural network has been collected for
248 randomly selected mesh. This represents $1 \%$ of whole 100-meter $\times 100$-meter grid. For those selected mesh fields, through the analysis of the topographic map (scale $1: 50 \mathrm{~K}$ and $1: 10 \mathrm{~K}$ ), orthophotomaps and interpretation of the factors which are important from the point of view of wind farm localization (Tab. 1), the index of wind farm localization possibility was assigned $\left(\mathrm{I}_{1}\right.$ factor, it was done by a spatial planning specialist). He assigned a value from 0 (on a mesh where it is not possible to place a wind turbine e.g. forest, built-up area, etc.) to 1 (for the meshes located in the open area, away from natural or artificial obstacles). It was also permissible to assign intermediate values (e.g. 0.4). These data were used to train the neural network, and for selection of the optimal network architecture by the Statistica software used. That is why a trained neural network was able to return in the output the index of localization $\left(\mathrm{I}_{1}\right)$ in the continuous range between 0 and 1 . The randomly selected squares of the grid are shown in Fig. 4. As a result of this operation, 248 sets of input data were obtained (seven parameters described above and one parameter which was the value of the expected neural network output). The reference data was used for neural network learning, i.e. adjusting the weight to the input data. In that way, the neural network is able to find the relationships between the various elements of the land cover and the expected, indicated by the operator, output value of artificial neural network $\left(\mathrm{I}_{1}\right)$. 
Table 1. Obtained parameters of land cover to the input of neural network; all 7 parameters are obtained for each 100 by $100 \mathrm{~m}$ grid

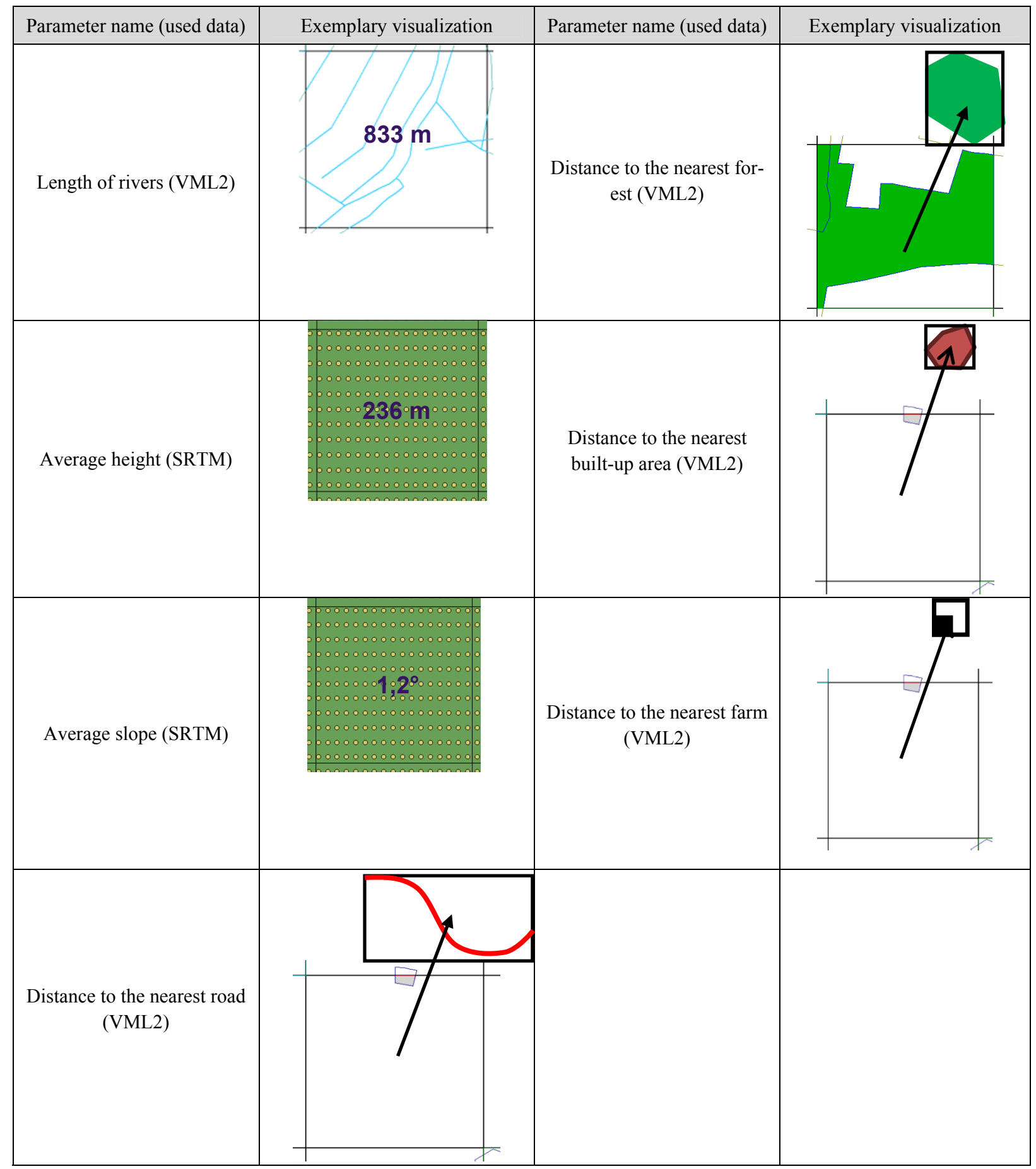

Source: own study.

In this study a feedforward neural network (perceptron) has been used, which consists of three layers. Input data are added to the first layer, and normalized to the interval $<0,1>$ according to the featured scaling method [DODGE et al. 2003]:

$V^{\prime}=\frac{V-V_{\min }}{V_{\max }-V_{\min }} \cdot\left(\right.$ new_max $\left.-n e w_{-} \min \right)+n e w_{-} \min (3)$ with $V$ being an input value and the $V^{\prime}$ - normalized value of input. Consequently, $\left[V_{\min }, V_{\max }\right]$ is the interval of input data and [new_max, new_min] is a new data range $[0,1]$.

Operations connected with data processing in neural networks were performed using the Statistica software version 12.5. The functioning of the neural networks functioning was significantly influenced by the selection of the proper network architecture 


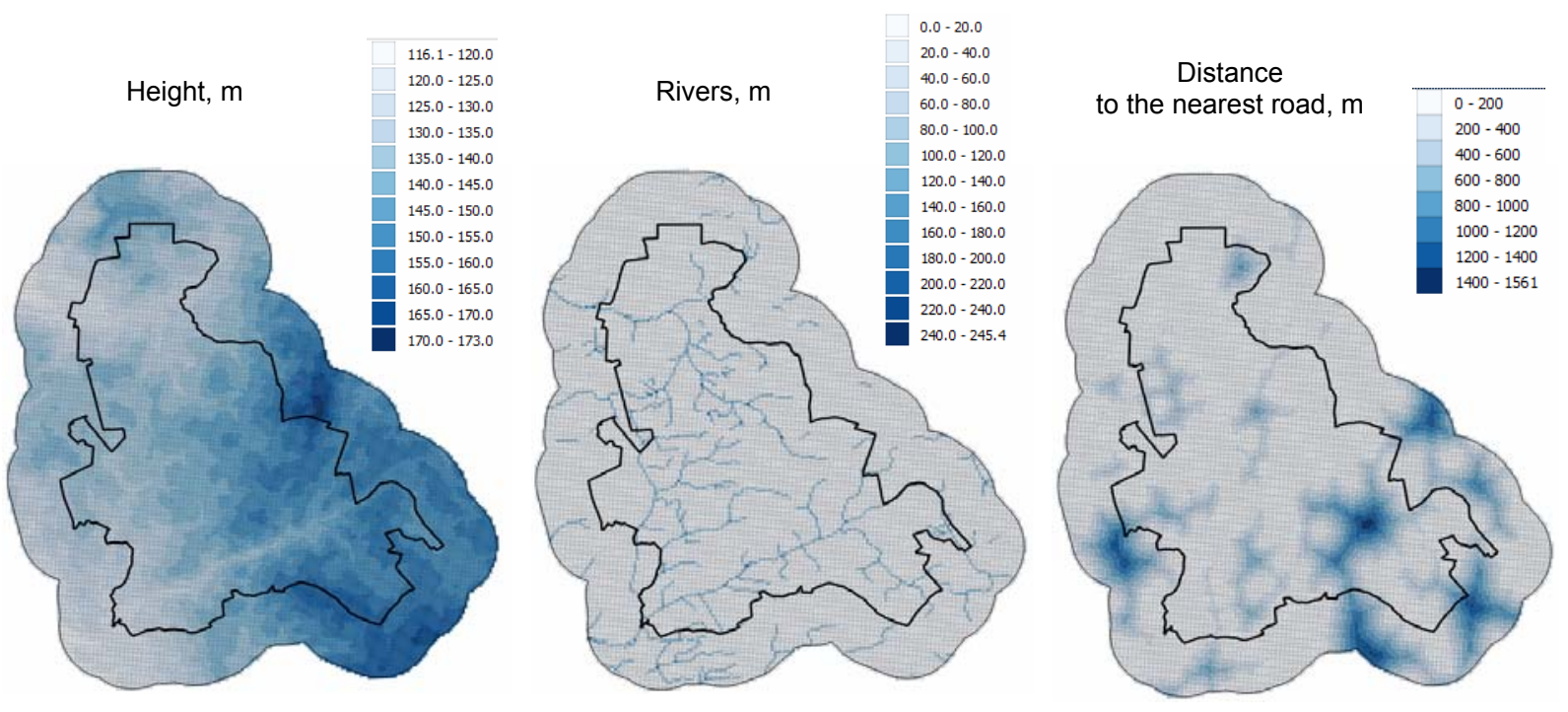

Fig. 3. Visualization of prepared data; source: own elaboration

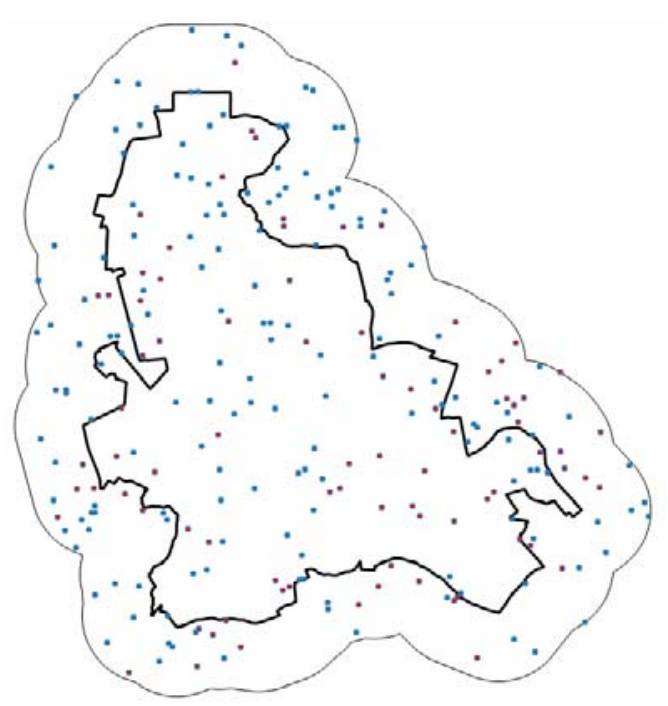

Fig. 4. Randomly selected squares of the grid; source: own study (eg. activation function, number of training iterations etc.). For this purpose, an "automatic network design" algorithm, included in the Statistica Software, was used. In order to find the optimal network architecture, the cross-validation method [ĆWIK et al. 2009] was used. The learning set was split into three subgroups: a learning sample (70\% of the samples) for training the network, a test sample (15\%), which was used to control the learning process, and a validation sample (15\%), used for verification and final selection of the best network. Selection of cases for each sample was done through a random drawing process. The operation of the algorithm used for finding the optimal network architecture is based on generation of multiple neural networks (in this analysis 20,000 networks were prepared). From the generated networks, 10 were selected (Tab. 2), for which the quality factor of the network for the validation sample was the highest [SZALENIEC 2008].

Table 2. Selected artificial neural networks (ANN)

\begin{tabular}{|c|c|c|c|c|c|c|c|}
\hline Id & ANN & $\begin{array}{c}\text { Quality } \\
\text { (learning) }\end{array}$ & $\begin{array}{c}\text { Quality } \\
\text { (testing) }\end{array}$ & $\begin{array}{c}\text { Quality } \\
\text { (validation) }\end{array}$ & $\begin{array}{c}\text { Learning algorithm, } \\
\text { no. of iterations }\end{array}$ & $\begin{array}{c}\text { Function of activation } \\
\text { (hidden layer) }\end{array}$ & $\begin{array}{c}\text { Function of activation } \\
\text { (output layer) }\end{array}$ \\
\hline 1 & MLP 7-4-1 & 0.870518 & 0.792836 & 0.963813 & BFGS 98 & logistic & tanh \\
\hline 2 & MLP 7-7-1 & 0.893824 & 0.891109 & 0.970592 & BFGS 33 & exponential & logistic \\
\hline 3 & MLP 7-9-1 & 0.911334 & 0.864444 & 0.963164 & BFGS 39 & exponential & exponential \\
\hline 4 & MLP 7-7-1 & 0.915527 & 0.856749 & 0.957333 & BFGS 51 & tanh & logistic \\
\hline 5 & MLP 7-6-1 & 0.913964 & 0.805718 & 0.960582 & BFGS 80 & tanh & liniowa \\
\hline 6 & MLP 7-20-1 & 0.897012 & 0.868920 & 0.953020 & BFGS 30 & exponential & exponential \\
\hline 7 & MLP 7-9-1 & 0.921326 & 0.851181 & 0.953163 & BFGS 64 & exponential & logistic \\
\hline 8 & MLP 7-5-1 & 0.876676 & 0.807389 & 0.954796 & BFGS 49 & logistic & logistic \\
\hline 9 & MLP 7-22-1 & 0.922512 & 0.823742 & 0.957519 & BFGS 95 & exponential & exponential \\
\hline 10 & MLP 7-19-1 & 0.887282 & 0.871934 & 0.955118 & BFGS 23 & tanh & logistic \\
\hline
\end{tabular}

Source: own study.

\section{RESULTS AND DISCUSSION}

For each network a "quality" was appointed. This was an estimator, determining the suitability of the network to selecting the area suitable for wind farm installation. This coefficient was determined separately for a learning, testing and validation sample. It is the correlation coefficient between the output variable and its prediction made by the neural network. The high coefficient demonstrates the correct 
compliance of the predicted values with the values of the dependent variable. The coefficients varying from 1 (perfect match) demonstrates a natural noise for the results of measurements and the fact that the network is not "overtrained" and still has the ability to generalize knowledge acquired in the learning process [SZALENIEC 2008] (Tab. 2).

In selected neural networks, the first layer is responsible for entering the input data. There are 7 standardized (Fig. 3) quantitative parameters (Tab. 1) entered into the neural network. The second layer is responsible for processing previously entered data (depending on the network, it has a different number of neurons, see Tab. 2). The third layer (output) forms a single neuron, generating at its output an index of wind farm localization possibilities (in the continuous range 0 to 1$)$. To determine the value of the initial weights, random number generator was used. In order to determine the weights of neurons a supervised learning method with a teacher was used, according to the BFGS (Broyden-Fletcher-Goldfarb-Shanno) method [NAZRI et al. 2006].

To carry out the process of neural network learning, an average 68 iterations of learning was sufficient (learning was interrupted when a rise in validation errors occurred). The algorithm of neural network selection tested different configurations of using the activation function. For the entered data, the highest correlation coefficient of the output data with data in the validation set was obtained using logistic, exponential and hyperbolic tangent functions (see Tab. 2).

In order to assess the impact of individual input variables on the value of output, a global sensitivity analysis was performed. It consisted of checking the behaviour of the network error after exclusion of individual independent variables from analysis. In the analysis, the value of each input variable was converted to the average (variable ceased to enter any information). After inserting such modified data at the input of the network, the final prediction error was checked. When it was large, it meant that the variable had a significant impact on the final result. If it fluctuated within value of 1 , it meant that it had little ef- fect on the final output of the neural network (Table 3 ). Analysis of global sensitivity shows that the greatest impact on the result value returned by the neural network was forest areas and rivers. This is due to the fact that these elements of land cover constitute relatively large areas in the study. Moreover, their occurrence in the area of the mesh results in an automatic assignment of 0 for the training data. Distance from roads, built-up areas and farms has less impact on the final results due to the smaller number of these objects in the analyzed area. Especially noticeable is the coefficient close to the value of 1 (no impact on the output of the network) for items related to the relief (height and slopes). The reason for this is a lack of any denivelation in the area of the Miedzna district, which made it impossible to consider this factor during preparation of the training data. During the preliminary studies, an analysis was carried out in which those two factors were removed. The results showed that reducing the number of factors did not affect the final result in any way, compared with studies in which these variables were taken into account. These variables were not removed deliberately, because those factors could have a significant impact in other areas where denivelations are greater (the versatility of presented solution).

It is important to highlight the fact that the results of a sensitivity analysis apply only to the case study (the Miedzna district). If the examination were to be carried out in areas where there are fewer forests and more built-up areas and roads, their impact on the output index of wind farm localization would be probably higher.

After the process of learning, the artificial neural networks have been tested. For this purpose, data (Tab. 1) from all squares of 100 to $100 \mathrm{~m}$ grid (24 755 mesh) have been entered to the neural network. This data was processed by 10 previously trained artificial neural networks. The final result equaled the average value of the output neuron for each of the 10 previously prepared networks. Visualization of the results generated by the neural network is presented in Fig. 5.

Table 3. Results of analysis of global sensitivity

\begin{tabular}{|c|c|c|c|c|c|c|c|c|}
\hline Id & ANN & $\begin{array}{c}\text { Distance to } \\
\text { the nearest } \\
\text { forest }\end{array}$ & $\begin{array}{c}\text { Length of } \\
\text { rivers }\end{array}$ & $\begin{array}{c}\text { Distance to } \\
\text { the nearest } \\
\text { road }\end{array}$ & $\begin{array}{c}\text { Distance to the } \\
\text { nearest built-up } \\
\text { area }\end{array}$ & $\begin{array}{c}\text { Distance to } \\
\text { the nearest } \\
\text { farm }\end{array}$ & $\begin{array}{c}\text { Average } \\
\text { height }\end{array}$ & $\begin{array}{c}\text { Average } \\
\text { slope }\end{array}$ \\
\hline 1 & MLP 7-4-1 & 6.72 & 10.28 & 2.02 & 1.50 & 1.31 & 1.05 & 1.03 \\
\hline 2 & MLP 7-7-1 & 10.96 & 3.46 & 1.88 & 1.47 & 1.58 & 1.17 & 1.02 \\
\hline 3 & MLP 7-9-1 & 14.66 & 3.41 & 1.99 & 1.58 & 1.47 & 1.13 & 0.99 \\
\hline 4 & MLP 7-7-1 & 10.93 & 5.75 & 1.91 & 1.50 & 1.35 & 1.04 & 1.03 \\
\hline 5 & MLP 7-6-1 & 11.74 & 7.89 & 2.48 & 1.19 & 1.56 & 1.04 & 1.05 \\
\hline 6 & MLP 7-20-1 & 47.00 & 3.69 & 2.89 & 1.49 & 1.44 & 1.44 & 1.00 \\
\hline 7 & MLP 7-9-1 & 15.48 & 8.13 & 2.30 & 1.70 & 1.57 & 1.39 & 1.08 \\
\hline 8 & MLP 7-5-1 & 8.35 & 2.82 & 1.87 & 1.26 & 1.60 & 1.06 & 0.99 \\
\hline 9 & MLP 7-22-1 & 12.42 & 7.99 & 2.51 & 2.10 & 1.46 & 1.16 & 1.30 \\
\hline 10 & MLP 7-19-1 & 10.55 & 3.39 & 1.88 & 1.34 & 1.45 & 1.17 & 1.02 \\
\hline & Average & 14.88 & 5.68 & 2.17 & 1.51 & 1.48 & 1.16 & 1.05 \\
\hline
\end{tabular}

Source: own study. 


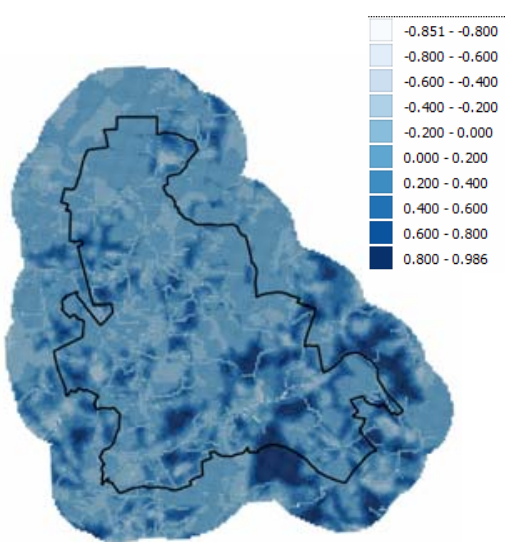

Network 1, 7-4-1

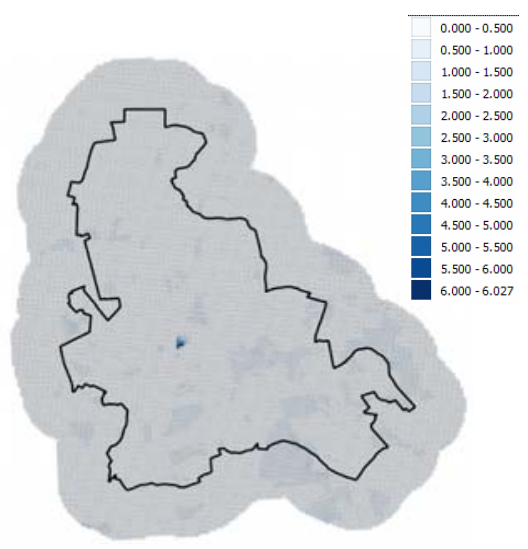

Network 6, 7-20-1

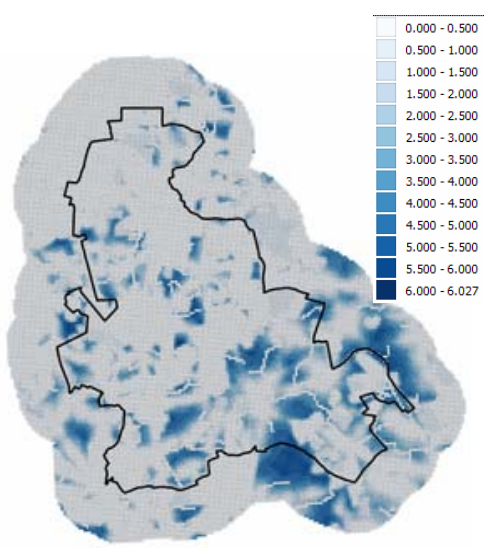

Network 3, 7-9-1

Fig. 5. Visualizations of the results generated by the neural networks; source: own elaboration

Although the outputs generated by different neural networks are varied (in terms of the value assigned $\mathrm{I}_{1}$ factor), we can distinguish the same areas in all visualizations for which the neural network has assigned a high index value. After adding the most important elements of land cover to the map, it can be observed that the group of neural networks properly marked areas located within a few hundred meters from obstacles, such as urban areas, forests and roads (Fig. 6). Moreover, the $100 \times 100$-meter grid squares more distant from these obstacles were assigned a higher index at the output of the neural network than the ones that were closer to those obstacles. As a result, there is a possibility of drawing a gradient line, along which the smooth change of the resulting index appears. Due to the small size of the grid used $(100 \times$ $100 \mathrm{~m})$, the data is so accurate that visualization resemble maps showing areas predisposed to wind turbine location in the form of isolines.

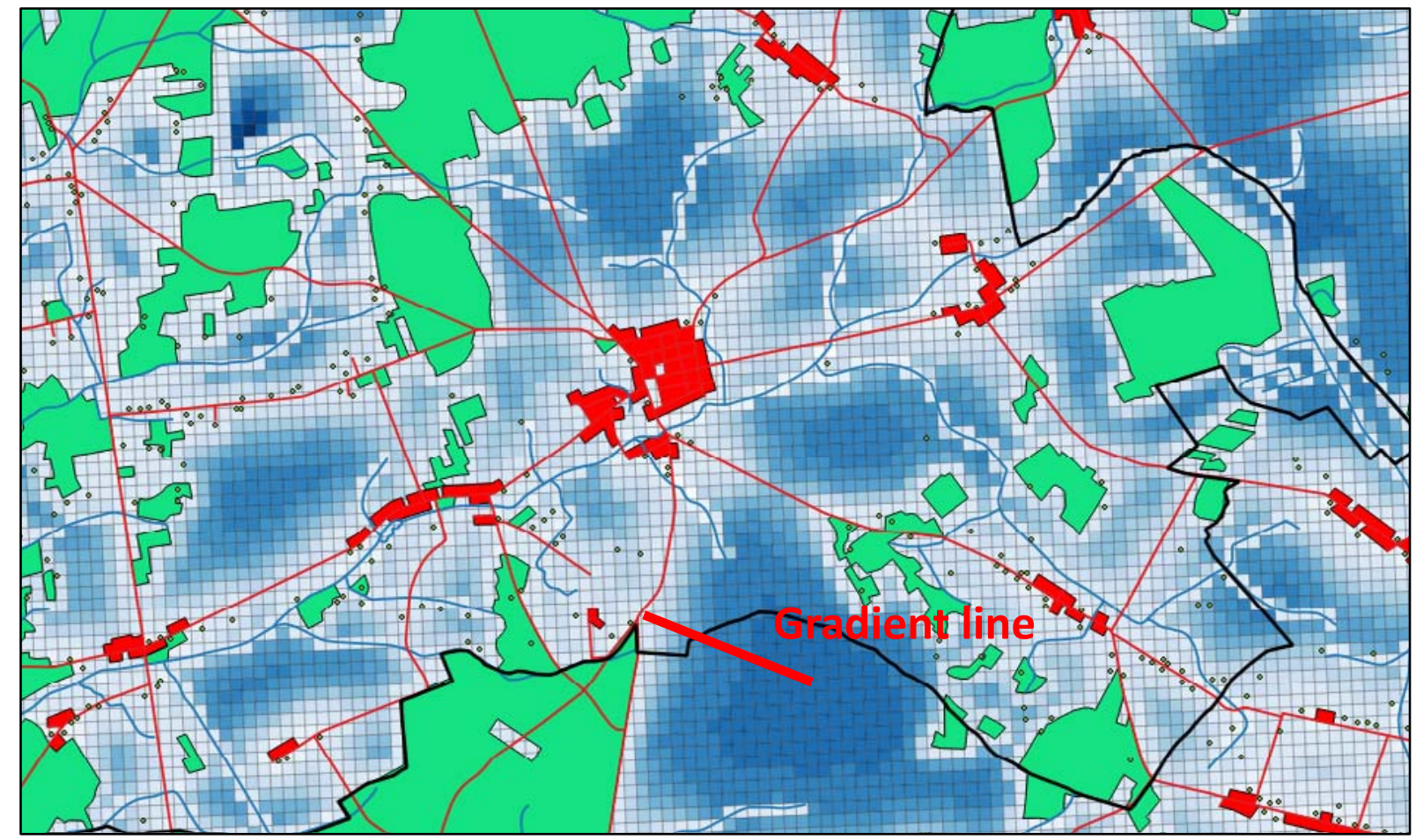

Fig. 6. Visualization of the results generated by team of neural networks and elements of land cover; source: own elaboration

\section{SUMMARY}

Areas designated by the artificial neural network areas have been marked on the topographic maps and orthophotomaps (Fig 7). This analysis shows that the selected areas are mostly flat farmland, a few hundred meters away from the natural and anthropogenic barriers adversely affecting the ability and capacity of wind power in the analyzed area. An example of such an area is highlighted in Figure 7. This area is located to the south of Miedzna. It has an area of approx. $4 \mathrm{~km}^{2}$ and allows the location of several dozen wind 

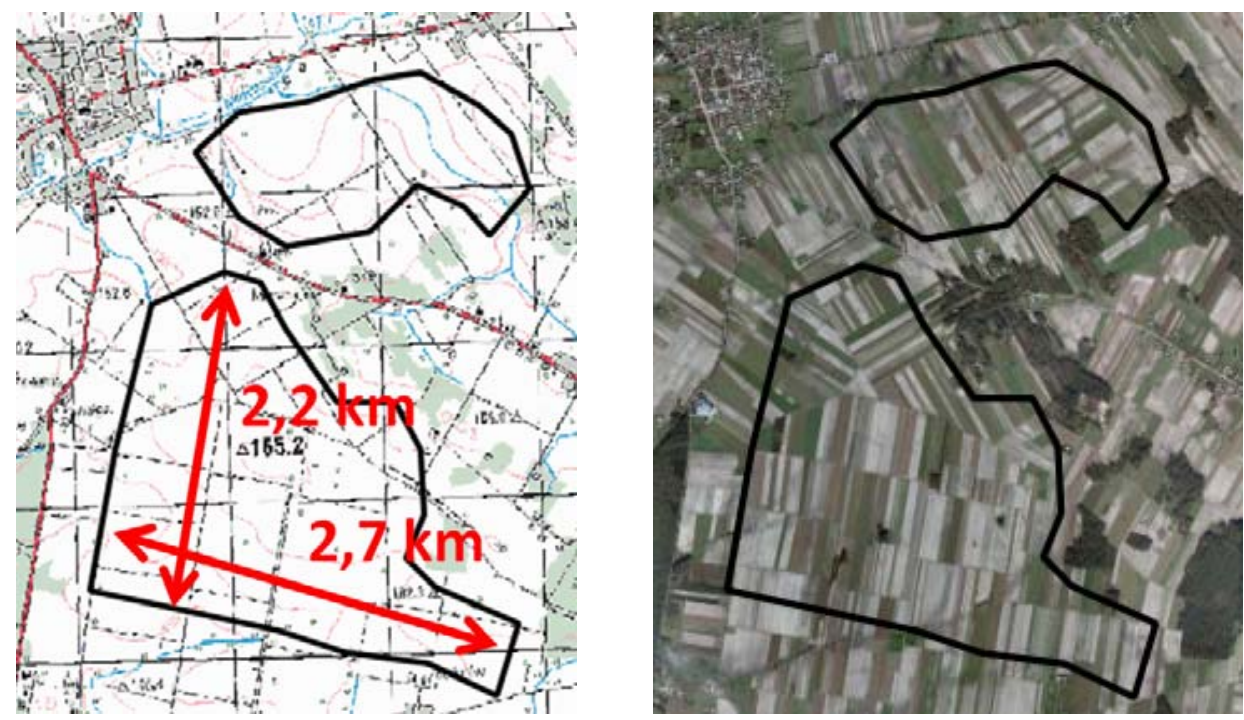

Fig. 7. Areas selected by neural network; source: own elaboration

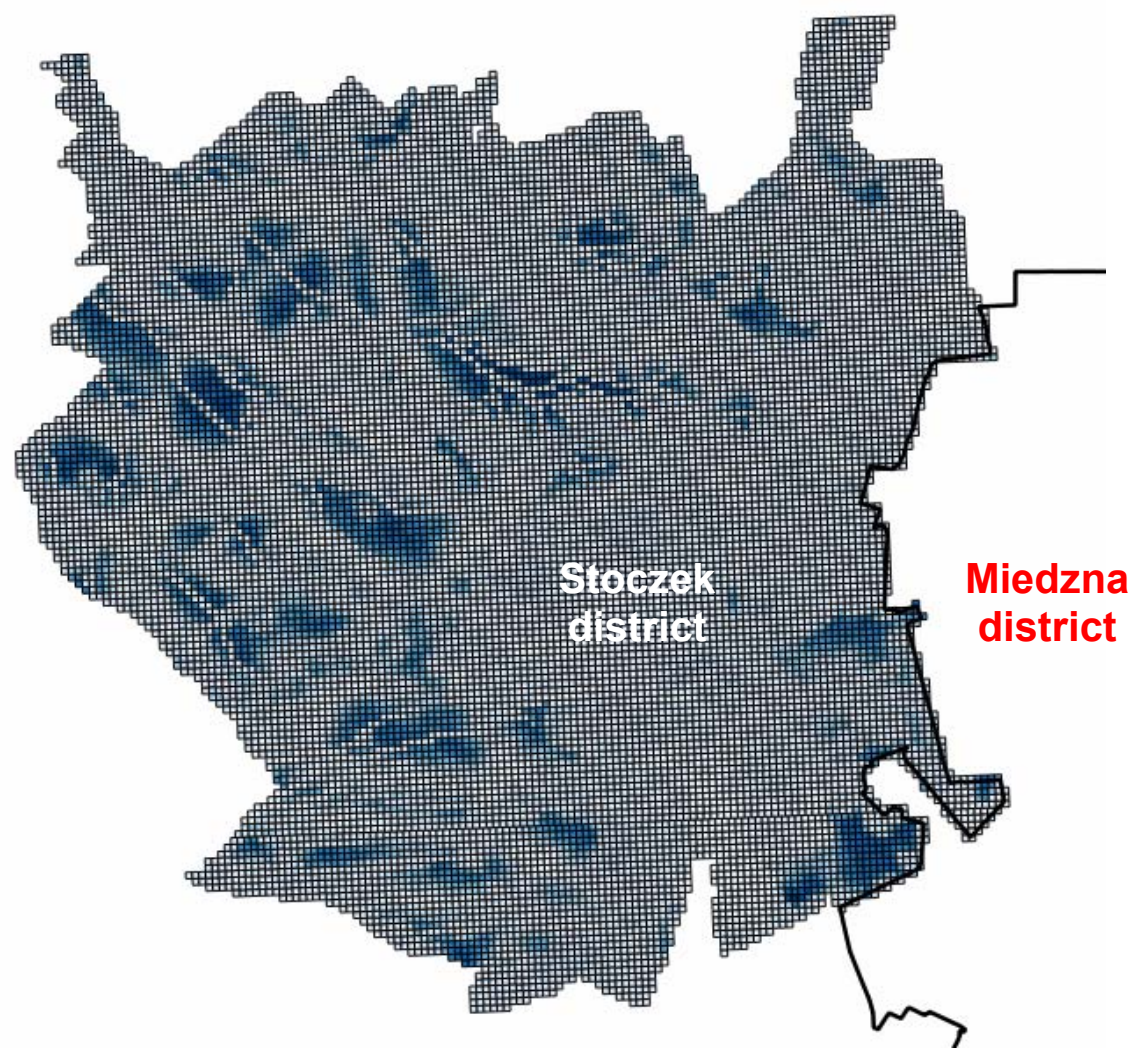

Fig. 8. Result of analysis conducted on the neighbouring district; source: own elaboration

turbines which are able to provide electricity for the whole Miedzna district. Studies show that a properly trained neural network (using a representative number of samples and for the appropriate architecture), makes it possible to carry out the process of automation of area classification in terms of placement of the wind turbines. As expected, indexes close to one received squares farthest from any natural or artificial obstacles.

Preparation of training and test data is a very time-consuming and complicated process (for each object 7 parameters related to the land cover must be collected). To automate this process, an application which prepares a grid of squares for neural networks has been developed. The usage of this program makes it possible to gather data automatically for the area of the Miedzna district in approx. 24 hours (using a standard PC with a quad-core processor). The process of neural network learning took another 2 hours. The processing of data through the network for tens of thousands of grid squares took single seconds.

After the author's analysis of generated maps of the optimal location of wind turbines, and taking into account the recommendations contained in the manu- 
als of the Statistica software, the best results are obtained for the team of generated artificial neural networks. The final value of the network output is calculated as the average of the outputs of individual neural networks. Usage of artificial neural networks allows for the analysis of all the objects in the topographic database (not only objects in the area, where the learning process has been conducted). In order to prove this, input data for the area of the neighboring district Pionki was gathered and inserted into the previously trained artificial neural network (Fig. 8). The comparison of the results with the content of a topographic map confirms that the proposed methodology can be used in any area. Further directions of research will proceed towards increasing the number of parameters taken into account by the neural network. In order to be able to use trained artificial neural network over a larger area, more data concerning the elements of land cover should be entered into the neural network (e.g. lakes, marshes, soil type, etc.).

\section{Acknowledgements}

This research was conducted on the basis of Vector Map Level 2 obtained from Polish Military Directorate.

The SRTM digital terrain models were obtained from NASA's resources (http://www2.jpl.nasa.gov/srtm).

Processing of spatial data was performed using the DotSpatial library (www.dotspatial.codeplex.com) and QGIS software (www.qgis.org).

This research is supported by the Faculty of Civil Engineering and Geodesy of the MUT statutory research funds $(933 / 2016)$.

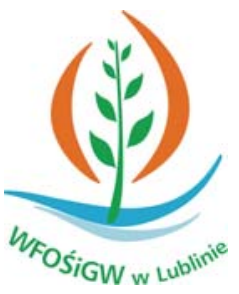

Dofinansowano ze środków

Wojewódzkiego Funduszu Ochrony Środowiska

i Gospodarki Wodnej w Lublinie

Cofinanced by Voivodeship Fund

for Environmental Protection and Water Management in Lublin

\section{REFERENCES}

ARE 2014. Statystyka Elektroenergetyki Polskiej [Polish electric power statistics]. ISSN 1232-2415.

BAGHERI BODAGHABADI M., MARTINEZ-CASASNOVAS J.A., SAlehi M.H., Mohammadi J., Esfandiarpoor BorUJENI I., TOOMANiAn N., GANDOMKAR A. 2015. Digital soil mapping using artificial neural networks and terrain-related attributes. Pedosphere. Vol. 25. Iss. 4 p. 580-591. DOI: 10.1016/S1002-0160(15)30038-2.

ĆWIK J., MieliŃCZUK J. 2009. Statystyczne systemy uczące się. Ćwiczenia w oparciu o pakiet R. Warszawa. Oficyna Wydaw. PW. ISBN 978-83-7207-838-4 pp. 192.

DoDGE Y. (ed.) 2003. A dictionary of statistics. Oxford. Oxford University Press. ISBN 0-19-850994-4 pp. 506.

Energetyka Cieplna i Zawodowa 2009-2010. Vol. 12/2009, 1/2010. ISSN 1734-7823.

GWEC 2014 Global wind statistics [online]. [Access 05.05.2016]. Available at: http://www.gwec.net/wp-
content/uploads/2015/02/GWEC_GlobalWindStats 2014_FINAL 10.2.2015.pdf

Jing L., Ji-HANG $\bar{C}$., JING-YUAN S., FeI H. 2012. Brief introduction of Back Propagation (BP) neural network algorithm and its improvement. In: Advances in Computer Science and Information Engineering. Eds D. Jin, S. Lin. T. 2. Vol. 169. Berlin Heidelberg. Springer p. 553558.

LeE S., SONG K.-Y., KIM Y., PARK I. 2012. Regional groundwater productivity potential mapping using a geographic information system (GIS) based artificial neural network model. Hydrogeology Journal. Vol. 20. Iss. 8 p. 1511-1527. DOI: $10.1007 / \mathrm{s} 10040-012-0894-7$.

LORENC H. (ed.) 2005. Atlas klimatu Polski [Atlas of the climate of Poland]. Warszawa. IMGW. ISBN 83-8889743-8 pp. 116.

Montusiewicz J., Gryniewicz-Jaworska M., Pijarski P. 2015. Looking for the optimal location for wind farms. Advances in Science and Technology-Research Journal. Vol. 9. Iss. 27 p. 135-142. DOI: 10.12913/22998624/ 59095.

NAZRI M.N., Meghana R.R., Rajesh S. 2006. Ransing an improved learning algorithm based on the BroydenFletcher-Goldfarb-Shanno (BFGS) method for back propagation neural networks. Sixth International Conference on Intelligent Systems Design and Applications. Vol. 1 p. 152-157. DOI: 10.1109/ISDA.2006.95. Publisher: IEEE.

NOOROLlAHI Y., JOKAR M.A., KALHOR A. 2016. Using artificial neural networks for temporal and spatial wind speed forecasting in Iran. Energy Conversion and Management. Vol. 115 p. 17-25. DOI: 10.1016/j.enconman. 2016.02.041.

OpenStreetMap undated. OpenStreetMap wiki page for Miedzna (gmina) [online]. [Access 05.05.2016]. Available at: https://commons.wikimedia.org/w/index.php? curid $=36071206$

SUZUKI K. 2013. Artificial neural networks - architectures and applications [online]. InTech. ISBN 978-953-510935-8 pp. 264. DOI: 10.5772/3409. [Access 05.05.2016]. Available at: http://www.intechopen.com/ books/artificial-neural-networks-architectures-andapplications

SZALENIEC M. 2008. Sieci neuronowe i regresja wieloraka czyli jak okiełznać złożoność w badaniach naukowych? [Neural networks and multiple regression. How to tame the complexity of scientific research?] [online]. StatSoft. [Access 02.10.2016]. Available at: http://www.statsoft. pl/Portals/0/Downloads/Sieci\%20neuronowe.pdf

TAURON Ekoenergia undated. Farma wiatrowa Marszewo [Marszewo wind farm] [online]. [Access 05.05.2016]. Available at: http://www.tauron-ekoenergia.pl/ elektrownie/energia-z-wiatru/farma-wiatrowa-marszewo

URE undated. Mapa odnawialnych źródeł energii [Map of renewable energy sources] [online]. [Access 05.05.2016]. Available at: https://www.ure.gov.pl/ uremapoze/mapa.html

Vestas undated. V90-2,0 MW platform [online]. [Access 02.10.2016]. Available at: https://www.vestas.com/en/ system/links/media-links/product-media/brochures/uk/ 2mw-product-brochure

WidROW B., LEHR M.. 1990. 30 years of adaptive neural networks - perceptron, madaline, and backpropagation. Proceedings of the IEEE. Vol. 78. Iss. 9 p. 1415-1442. DOI: $10.1109 / 5.58323$. 


\section{Krzysztof POKONIECZNY}

\section{Wykorzystanie sztucznych sieci neuronowych do wyznaczania lokalizacji elektrowni wiatrowych na przykladzie gminy Miedzna}

\section{STRESZCZENIE}

Zgodnie z obowiązującymi w Polsce regulacjami prawnymi użytkowanie elektrowni wiatrowych podlega odpowiednim uwarunkowaniom. Obostrzenia te dotyczą zarówno parametrów technicznych tych urządzeń, które związane są z bezpieczeństwem ich eksploatacji, jak i uwarunkowaniami przestrzennymi, związanymi z lokalizacją tych elektrowni oraz ich odległości od takich elementów pokrycia terenu, jak zabudowa czy lasy. Problematyka ta jest szczególnie istotna $\mathrm{w}$ kontekście częstych protestów mieszkańców, w sąsiedztwie których takie elektrownie mają być budowane.

W celu wyznaczenia obszarów optymalnych dla lokalizacji elektrowni wiatrowych wykorzystano jedną z metod uczenia maszynowego, którą są sztuczne sieci neuronowe. Ich istota, a jednocześnie przewagą nad metodami bazującymi na zadanym algorytmie, jest zdolność do uogólnienia otrzymywanych wyników, gdy algorytm rozwiązania danego problemu nie jest prosty (jak w przypadku wyznaczania obszarów szczególnie predestynowanych do lokalizacji elektrowni wiatrowych).

$\mathrm{W}$ artykule przedstawiono metodykę zastosowania jednego rodzaju sieci neuronowych, którym jest perceptron wielowarstwowy. W zastosowanej sieci wykorzystano metodę nauczania nadzorowanego z nauczycielem, polegającą na wskazywaniu sieci neuronowej wzorcowego rozwiązania z określonymi danymi wejściowymi, którymi są parametry związane z pokryciem terenu i sąsiedztwem przestrzennym pola podstawowego, tj. kwadratu o wymiarach $100 \times 100 \mathrm{~m}$.

Jako studium przypadku wybrana została gmina Miedzna, która znajduje się we wschodniej części województwa mazowieckiego i jest gminą wiejską o charakterze rolniczym. Obszar gminy leży na falistej wysoczyźnie morenowej, urozmaiconej morfologicznie. Otwarte pola uprawne oraz lekko pofałdowany teren to dwa główne czynniki sprzyjające możliwości rozmieszczenia farm wiatrowych na danym terenie. W zaprezentowanych w artykule przykładach wykorzystane zostały dane przestrzenne pochodzące z Vector Map Level 2 oraz dane wysokościowe Shuttle Radar Topography Mission (SRTM).

W wyniku przeprowadzonych eksperymentów dowiedziono, że poprawnie nauczona sieć neuronowa (z wykorzystaniem reprezentatywnej liczby próbek i odpowiednią architektura), umożliwia poprawne wyznaczenie obszarów predestynowanych do lokalizacji elektrowni wiatrowych nie tylko na terenie gminy Miedzna, ale również innych gmin, automatyzując proces wykonywania analiz tego typu.

Słowa kluczowe: elektrownie wiatrowe, perceptron wielowarstwowy, sztuczne sieci neuronowe 